\title{
Phytopathology"
}

\section{Problem Setting and Problem Solving in the Case of Olive Quick Decline Syndrome in Apulia, Italy: A Sociological Approach}

\author{
Christian Colella, ${ }^{\dagger}$ Roberto Carradore, and Andrea Cerroni
}

Department of Sociology and Social Research, University of Milano-Bicocca, Milan, 20126, Italy.

Accepted for publication 17 December 2018.

\begin{abstract}
This article gives an account of the social construction of phytopathological knowledge in the case of olive quick decline syndrome (OQDS) in Apulia, Italy. Due to the economic, cultural, and social importance of the olive crop, the spread of this disease has been characterized by a social debate over the implementation of mandatory phytosanitary policies, the etiological role played by the bacterium Xylella fastidiosa, the role of scientific experts, and the unexplored research trajectories ("undone science") proposed by social and environmental movements. We examine how the disease has generated different approaches to problem setting and problem solving, one focused on OQDS as a complex of symptoms uniquely caused by $X$. fastidiosa, and the other framing the study of "complesso del disseccamento rapido dell'olivo" (CoDiRO) as a complex of causes. Drawing on a 2-year ethnographic study among researchers, policymakers, agricultural stakeholders, and social movements, this article uses theoretical concepts from the sociology of knowledge, sociology of scientific knowledge, and sociology of ignorance to examine the case and to reconstruct the $360^{\circ}$ approach proposed by social movements as an alternative to the epistemic and political reductionism of official phytosanitary and science policies.
\end{abstract}

"Science, if it can deliver truth, cannot deliver it at the speed of politics." (Collins and Evans 2002)

The case of olive quick decline syndrome (OQDS) in Apulia, Italy represents an example of how a specific technical scientific problem can be perceived differently by a wide range of different actors, and how environmental and social movements, through organized action, can reach into the epistemic and political field, proposing alternative scientific research strategies and technical solutions and, thus, shaping the public perception of scientific research, scientific experts, and science policies. In this article, we explore how the presence of the bacterium Xylella fastidiosa subsp. pauca and OQDS generated a schism between different actors, groups, and institutions which propose divergent approaches to problem setting ("What is this?") and problem solving ("What do we do?"). We will see how these approaches diverge from each other depending on "what is at stake" for actors, groups, and institutions.

The exceptional nature of OQDS in Apulia is based on the fact that most of the olive trees in this region are centuries old and, thus, cherished for their ecological and cultural value. Unfortunately, OQDS is an incurable disease, and the only available solution is to

${ }^{\dagger}$ Corresponding author: Christian Colella; E-mail: c.colella2@campus.unimib.it

The author(s) declare no conflict of interest.

(c) 2019 The American Phytopathological Society reduce the spread of both the pathogen and its insect vectors with eradication measures, containment strategies, and vector control. Phytosanitary policies have been largely criticized and strongly opposed by some local administrators, the general public, and, most notably, organized social and environmental movements. However, the core of the criticism produced by Apulian movements is not directed solely against the uprooting of olive trees; instead, social movements propose a completely different approach toward plant pathogeneses. According to them, the decline of olive trees is not caused (or at least, not uniquely caused) by $X$. fastidiosa. Social movements claim that there is no strong scientific evidence of a correlation between the bacterium and the disease; rather, they claim that the disease may be caused by a wide range of factors that contribute together to the emergence of OQDS symptoms. Such causes are identified in fungi and insects; environmental and physiological factors such as the lack of organic matter in soils (Xiloiannis et al. 2015); agrochemicals (Ciervo 2016); and even, as we will see in more detail later in this article, by social, political, and economic factors. Starting from this assumption, the problem-solving approach proposed by social movements mainly revolves around the possibility to cure already affected olive trees through traditional farming practices, pruning, fungicides, and organic fertilizers. Social movements maintain that these options are a priori excluded by the majority of scientists, research institutes, and scientific policies.

We examine this case based on the results of a 2-year ethnographic study in which we examined discourses on social networks; did participant observation in public events, technical courses, 
and seminars organized by experts, stakeholders, and social movements; and conducted in-depth interviews with scientists, administrators, stakeholders, and social movement representatives.

We will try to reconstruct the scientific process of "the making of plant pathology", and we will see how a complex of different causes ("complesso del disseccamento rapido dell'olivo" [CoDiRO]) ended up being considered and described as a complex of symptoms (OQDS). We will argue that social and environmental movements (not only activists but even experienced farmers and experts from different fields) refuse to focus their attention solely on the bacterium $X$. fastidiosa but, instead, propose a radical approach (which social movements call the " $360^{\circ}$ approach") aimed at dismantling the epistemic and political reductionism of phytosanitary and science policies.

One of the main features that has characterized the presence of $X$. fastidiosa in Apulia is its capacity to create and mobilize knowledge from the bottom up. Discussing (or being able to discuss) the bacterium has become, rightly or wrongly, a reflection of social relations and balances, a bacterium that reveals tensions between hegemonic and subaltern knowledge, between experts and "lay experts", and between center and periphery.

Knowledge societies run on expert processes and expert systems that are epitomized by science but are structured into all areas of social life (Knorr-Cetina 1999). In this article, we suggest that examining the case of OQDS in Apulia from the perspective of social sciences can help improve both science and science policy because, among the "many worlds" inhabited by the bacterium $X$. fastidiosa (Chatterjee et al. 2008), we might also find the cultural world and the social world.

\section{AN ECOLOGICAL PLAYGROUND FOR A VECTOR- BORNE PATHOGEN: A SOCIO- HISTORICAL BACKGROUND}

"It's slippery! ... See! Once we used to climb up wooden ladders, but they are not allowed anymore ... Now we have to use metal ladders... Do you want to know why? Because the lawmaker has never climbed up a tree in his life." (A farmer)

Apulia (southern Italy) has a significant sociohistorical heritage of olive growing. With over 60 million olive trees mainly composed of only two predominant cultivars (Luvisi et al. 2017), olive farming in Apulia dates back to pre-Roman times (Primavera et al. 2017); goes through the period of Charles III of Spain, who exempted his subjects who planted new olive groves from the payment of taxes in the 18th century (for the production of lamp oil used for public lightning); all the way up to Pierre Etienne Toussaint Ravanas, a French agronomist, who advanced olive growing and the production of olive oil in the mid-19th century (Mastrolia 1996, 2000; Mazzotti 2004). This centuries-long history of olive growing for many ends with Regulation Number 136/66/EEC of the Council of 22 September 1966, which established the granting of subsidies to olive-producing companies regardless of the quality of the final product and regardless of the type of agriculture practiced (Frascarelli 2017; Godini 2017; Sotte 2017). As a result, olive orchards, especially in the southern part of Apulia, were often left untreated and all but abandoned-interlocked human and nonhuman factors that, over time, may have created an ecological playground for the proliferation of a vector-borne pathogen.

In this social context, olive trees are, for many, considered more than a source of income; they represent the cultural history of a place, with all its contradictions and its reifications (Wagner 1981). Olive trees are a keystone of a dense network of ecological and socio-cultural meanings. They are everywhere but now, in southern Apulia, the overwhelming visual presence of ancient gnarled olive trees has been replaced by the bleak visible symptoms of an invisible threat.
Starting in 2010, the farming areas around Gallipoli experienced the first symptoms of a decline of olive trees characterized by leaf scorching and desiccation of twigs and small branches beginning in the upper part of the canopy, then extending to the rest of the crown, which acquired a burned look (Loconsole et al. 2014). The manifestation of symptoms in the plant was initially called CoDiRO or, in its English name, OQDS. Scientists determined that the etiological factor of OQDS is the bacterium $X$. fastidiosa subsp. pauca (Saponari et al. 2017), an organism whose detection anywhere in the European Union (EU) triggered immediate eradication and containment measures.

Indeed, the bacterium is known worldwide for being one of the greatest threats to agriculture and the environment, causing plant diseases such as Pierce's disease of grapevine in California, citrus variegated chlorosis in Brazil, and a number of diseases of perennial crops and landscape plants (Almeida and Nunney 2015; Purcell 2013; Purcell and Hopkins 1996). After its first detection in Apulia (Saponari et al. 2013), further investigations and experiments were conducted. Entirely new research programs were initiated to learn more about the threat for the old continent posed by this new "feral biology" (Swanson et al. 2018; Tsing 2015). The presence of $X$. fastidiosa in Apulia led to unprecedented research efforts to study the bacterium's biology (Saponari et al. 2017), insect vectors (Cornara et al. 2016, 2017), control strategies (Dongiovanni et al. 2016), diagnostics (Chiriacò et al. 2018; Zarco-Tejada et al. 2018), and disease dynamics (Strona et al. 2017; White et al. 2017).

However, local social movements as well as environmental and civic associations were seeking different research paths and different solutions which, in their view, should prioritize the search for a possible cure that could save the already affected, but still cherished, olive trees.

Well beyond the plants' physiology in the field, or what may later be observed in laboratory Petri dishes, the emergence of $X$. fastidiosa in Apulia also triggered a complex set of policies, legislation, and legal actions. Most notably, X. fastidiosa and the disease deriving from it initiated a set of social narratives about modern and traditional agriculture, about the role of experts and the limits of experience, and about which (and whose) knowledge and research is considered worthy of interest and support.

\section{THEORETICAL BACKGROUND}

Robert K. Merton (1910-2003) was one of the first sociologists to view science as an organized community composed of members who share common norms and values, hence inaugurating the field of sociology of science. However, the positivism-soaked sociological analysis of science of the 1950s and 1960s was not concerned with how and where scientific knowledge fits in a broader social and political structure (Collins and Restivo 1983). Indeed, this period has been named the "age of authority", in which a "truth class" (the scientific community) is clearly distinct from the rest of society. The sacredness of science started to decline with American physicist and historian of science Thomas S. Kuhn (1922-1962). The "ethos" of scientists proposed by Merton is scaled down to the idea of contextrelated paradigms shared by a certain community. According to historian of science David Roger Olroyd (1989), Kuhn's paradigm theory is both sociological and epistemological. A scientist adopts a paradigm which is produced by the community to which she/he belongs, as she/he also starts to see the world through the commitment generated by the paradigm itself.

Alexander Purcell, in "Paradigms: Examples from the bacterium Xylella fastidiosa" (Purcell 2013) uses Thomas Kuhn's theory of scientific revolutions (Kuhn 1962, 1970) to illustrate, through his personal experience as a scientist, the paradigm shifts that have occurred within the scientific community engaged in the research on Pierce's disease (PD). At first, PD was believed to be caused by a virus; this consolidated paradigm started to show its anomalies until 
it entered a state of crisis, a crisis that ended in the establishment of a new paradigm: PD is caused by a bacterium, later called $X$. fastidiosa (Purcell 2013). Around the same time, a paradigm shift was taking place in the social studies of science; in the early 1970s, social constructivism reconceptualized scientific knowledge as a social activity and addressed the need to draw on "extrascientific" factors to bring about the closure of scientific and technical debates and to direct attention on the use of scientific knowledge in social and political institutions (Barnes 1974, 1977; Bloor 1991). In this "age of democracy", citizens enter the processes of problem setting and problem solving of scientific issues, and the basis of technical and scientific decision making is widened beyond the core of experts. However, if citizens are legitimized to participate in the processes of problem setting and problem solving, how far should participation in technical decision making extend? (Collins and Evans 2002). As we will see, the "problem of extension" in technical and scientific political decision making is crucial to the analysis of OQDS in Apulia, especially within the dynamics between experts and members of the public.

Drawing on Brian Wynne's study on the relationship between Cumbrian sheep farmers and Ministry of Agriculture, Fisheries and Food scientists (Irwin and Wynne 1996; Wynne 1989) and Steven Epstein's case of patient's participation in the AIDS-treatment controversy (Epstein 1995, 1996), Collins and Evans focus their attention to the social role of members of the public who have special technical expertise by virtue of experience that is not recognized by degrees or other certificates (i.e., "experience-based experts") (Collins and Evans 2002; Selinger et al. 2007). In the "age of expertise", the "problem of legitimacy" (who is allowed to participate) is resolved by the "problem of extension" (how far the participation should go). This third wave of science studies, also referred to as Studies of Expertise and Experience, abandoned a strict distinction between a scientific community (an expert community) and laypersons (nonexperts) in favor of an analytical distinction that takes on the value of experience in a given field and its importance in the process of technical scientific policy making (for example, an experience gained in pest risk assessment, as well as the experience of an olive grower). For this reason, our analysis will be first epistemic and then political. Instead of applying a distinction between experts and nonexperts, we will frame models of problem setting and problem solving proposed or upheld by actors and, eventually, supported by policies.

Complementary to the field of Sociology of Scientific Knowledge, Sociology of Scientific Ignorance (Frickel and Vincent 2007; Frickel et al. 2010; Gross 2007, 2010; McGoey 2007; Böshen et al. 2006,2010 ) focuses on the social production of ignorance, not merely as a lack of knowledge but as a process embedded in the production of knowledge (Frickel and Gross 2005; Frickel and Moore 2006). Following Mathias Gross $(2007,2010)$ ignorance can be divided into three categories: (i) nonknowledge, the known unknowns that are considered worth pursuing; (ii) negative knowledge, knowledge deemed dangerous and not worth pursuing; and (iii) nescience, the lack of knowledge about the unknown (Frickel et al. 2010; Gross 2007).

Nonknowledge defines the epistemic and political boundary of what is essential to know (at a certain point of time, in certain contingencies) on a particular scientific question (for example, OQDS). The problem becomes who define these imperatives and who defines the boundaries of nonknowledge versus negative knowledge not worth pursuing: known unknowns considered worth pursuing by local scientific communities working on OQDS as a complex of symptoms uniquely caused by the bacterium $X$. fastidiosa versus those proposed by social movements and other scientific communities framing the study of CoDiRO as a complex of causes (Fig. 1).

In the literature, the term "undone science" refers to areas of research that are left unfunded, incomplete, or generally ignored but that social movements or civil society organizations often identify as worthy of more research (Frickel et al. 2010; Hess 2016). Undone science is a type of nonknowledge when viewed from the perspective of social movements but, from the perspective of some research communities, it may be viewed as negative knowledge (Frickel et al. 2010). Hence, if a particular type of science is privileged, an undone science is created. In our research, the concept of undone science is crucial, defining the unexplored territories of scientific action in the processes of problem setting and problem solving that social movements want to pursue.

However, undone science does not simply reflect a strict political division between scientists and nonscientists. Instead, our definition takes into account the temporal dimension of contingent policies that outline the urgency and convenience of some types of nonknowledge at the expense of others. Both of these types of nonknowledge are scientific, both may originate from laboratories, some gets to be done (here and now), and others will have to wait. Some is supported by social movements and others are contested.

\section{RESEARCH METHODOLOGY AND METHODS}

The aim of our research was to inquire into the sociotechnical imaginaries around OQDS as displayed by actors, groups, and institutions. The actors include political actors (at the European and regional levels), stakeholders (agricultural entrepreneurs and professional associations), scientific expertise (plant pathologists, virologists, entomologists, physiologists, those working on official OQDS research projects, and those outside), and social movements. These actors have different ways of presenting the problem (problem setting) and propose different solutions (problem solving).

The key social movements in the context of this study were "Il popolo degli ulivi" (Salento, southern Apulia) and "Comitato per la Salvaguardia Ambiente e Territorio della Valle d'Itria" (centralsouthern Apulia), The first group is older and is located in the infected area where the bacterium can no longer be eradicated, whereas the other group is located in the Containment Zone where more decisive phytosanitary policies are required but where the symptoms of the disease are less visible and olive trees appear healthy. For the sake of this contribution, we will not go into the details regarding their different group strategies and aims but, instead, try to frame their shared problem-setting and problemsolving approaches, especially compared with those proposed by political actors, scientific expertise, and agricultural stakeholders.

Technical and scientific literature review. As social scientists, at the onset of the study, we were not (and probably still are not) immersed in the concepts of molecular biology, entomology, plant pathology, ecology, plant physiology, and farming practices. We had first come in contact with knowledge produced regarding OQDS and $X$. fastidiosa trough scientific papers and technical policy documents. We had to develop a kind of familiarity with these fields and their objects.

The type of expertise that will serve us as a methodological tool for familiarization is called interactional expertise (IE) (Collins and Evans 2002, 2009, 2015; Collins et al. 2007). IE lays between two states, "no expertise" (starting point, insufficient to conduct a sociological analysis of the scientific field) and "contributory expertise" (sufficient expertise to actually contribute to the field being analyzed). IE means sufficient expertise to interact with participants, carry out a sociological analysis, and ask the pertinent questions about a practical skill or expertise (Collins 2004; Collins and Evans 2002, 2009). We began the process of socialization of OQDS and research on $X$. fastidiosa initially through papers, analyzing them based on authors' affiliations, expertise (disciplines or subfields), and journals (i.e., academic journals such as Journal of Plant Pathology and Phytopatologia Mediterranea as well as trade journals such as Informatore Agrario). We applied the same 
approach to technical documents and reports from the European Food Safety Authority (EFSA). IE also was also developed during conferences, workshops, and sometimes during interviews.

After the initial familiarization with the objects, we began to pursue the subjects. Social networks play a fundamental role in the dissemination of academic research (Nández and Borrego 2013). For this reason, we started following individual researchers working on OQDS and X. fastidiosa (but also other topics) on social networks such as ResearchGate or Academia.edu to stay up to date with the latest works of research communities working in Apulia, in Italy, and abroad. We considered papers from laboratories in Apulia, dividing them into groups: research from Bari (CNR-IPSP, DiSSPA UNIBA, CRSFA Basile Caramia, and CIHEAM-IAMB), research from Lecce (DiSTeBA-Unisalento), research from Foggia (UNIFG), and research from other laboratories and research institutes outside the region (CREA-FRC and DICEM-UNIBAS). These clusters were revealed to be particularly useful in framing different approaches to problem setting and problem solving in relation to the different kinds of scientific expertise involved (for example, pathology-centered approaches or physiology-centered approaches). Furthermore, we examined papers on other olive tree diseases in Apulia (Frisullo et al. 2014) and well-known diseases caused by the bacterium $X$. fastidiosa around the world such as PD in California and citrus variegated chlorosis in Brazil.

Digital ethnography of social media and social networks. As part of a "netnographic" approach, we decided to take into account the diversity of knowledge production spaces represented by communicative tools such as blogs, YouTube channels, and social networks. Indeed, social media and social networks represent one of the many worlds inhabited by the bacterium X. fastidiosa in Apulia. Social media platforms such as Facebook and Twitter have acted and continue to act as conceptual containers of knowledge about OQDS (Colella 2016). Activists, researchers, stakeholders, and sometimes even policymakers and politicians at local and national levels often use their private social network accounts as a dissemination tool to make their stances heard. Indeed, one of the conceptual battlegrounds in which conflicting knowledge about OQDS or CoDiRO collided has been Facebook. Hence, starting in 2015 to 2016, we monitored social media as noninteractive users (Kozinets and Handelman 1998; Shoham 2004) applying the noninterventionism of the naturalistic observation method (Adler and Adler 1994) to the public arena of social networks.

Members of social movements and the general public have used Facebook pages and groups for diverse purposes, from dissemination of "counter-knowledge" to political organization for public demonstration or the organization of events, agricultural courses, and public meetings. On Facebook, we also found some discussion spaces that offer advice on sustainable agronomic methods and traditional farming techniques aimed at reducing symptoms in affected olive trees. Social media are also used by groups and associations that represent stakeholders' stances. In fact, some of the agricultural entrepreneurs, together with scientists and research technicians, have engaged in science dissemination activities through websites, Twitter, and Facebook pages; one example is the website InfoXylella.it.

Another important tool used in this regard was the content change detection and notification service Google Alert using keywords

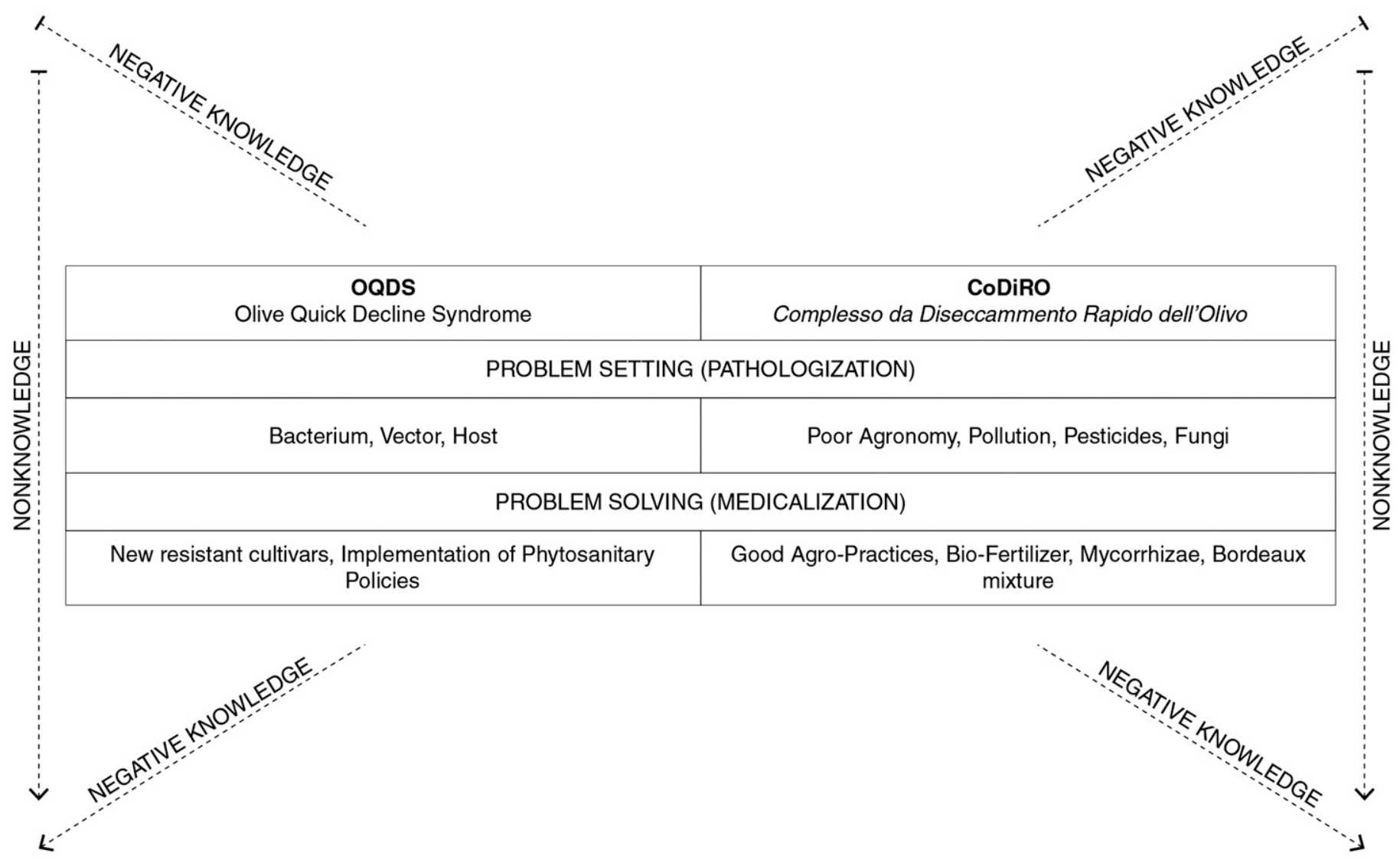

FIGURE 1

Visual representation of the dynamics between the nonknowledge of olive quick decline syndrome (OQDS; a complex of symptoms) and the nonknowledge of "complesso del disseccamento rapido dell' olivo" (CoDiRO; a complex of causes), using the theoretical model of sociology of ignorance (Frickel et al. 2010; Gross 2007). Nonknowledge in this context refers to the known unknowns that are considered worth pursuing; in contrast, negative knowledge is knowledge deemed dangerous and not worth pursuing. 
such as "Xylella", "Xylella fastidiosa", "OQDS", and "CoDiRO", which allowed us to obtain daily news feeds not only from Italian newspapers and blogs but also from across Europe and worldwide.

Even though this daily social media monitoring approach was revealed to be very useful, we must stress that it constituted a very small portion of the empirical data we collected. Indeed, the majority of our fieldwork has been conducted using more traditional sociological methodologies, which we will detail in the next section.

Public events and in-depth interviews. The main bulk of empirical data was collected via participant observation in public events and in-depth interviews made during the period of 2017 to 2018. A substantial part of the empirical data came from collective fieldwork with journalist Janos Chialà, anthropologist Enrico Milazzo (University of Turin), and geographer Michele Bandiera (University of Turin). Together, we conducted participant observations in 26 public events organized by stakeholders, administrators and policymakers, social movements, and researchers, and did 23 in-depth interviews with representatives of social movements and leading figures (sometimes activists as well as farmers), local administrators, stakeholders, and researchers.

Public events represent a quintessential place for creating and sharing a narrative and to institutionalize counter-knowledge, in which movements aim to establish alliances with members of the scientific community to gain epistemic and political credibility (Hess 2009; 2016) and with the intention to construct an IE (Collins and Evans 2002, 2009, 2015) with experts in the field that serves as a direct message to the policymaker and the public.

The events were organized by public administrations, stakeholders, researchers, and social movements and were scattered throughout the region. During each event, we interviewed and talked to participants and audience members, and wrote down any meaningful interaction that occurred. After each event, we dedicated time to the analysis of recorded data, the themes and the issues that emerged, and the interactions that took place. Events organized by public administrations were usually aimed at discussing the implementation of phytosanitary policies. Public events were also organized by economic stakeholders, including professional associations in the olive oil sector. These actors bring to the discussion reflections about the risks associated with the spread of the pathogen for the olive-products industry and farmers.

In our research, we included numerous events organized by social movements. The issue of social movements and science connects the anthropology and sociology of science with broader currents in science and technology studies as well as a sociology of social movements (Hess 2007). Movements hold meetings, conferences, and more-or-less-structured technical courses, in which agronomic knowledge is shared together with political stances and criticism toward the official handling of the phytosanitary emergency. Meetings, conferences, and courses are sometimes supported by local administrations and are held in cultural centers, libraries, and similar venues. These meetings are attended by a variety of participants, sometimes including researchers and local administrators, and offer a chance for the exchange of ideas about scientific research and scientific communication, agricultural techniques, environment and health issues, laws and regulations, journalism, and media activism. We also participated in demonstrations, at which representatives of social movements often speak to journalists and reporters to make their message heard.

Public events were crucial for reconstructing OQDS problem setting and problem solving imagined by different actors and the groups to which they belong but, sometimes, discourses pertaining the public sphere are just the tip of the iceberg. To fill the interpretative vacuum, we conducted 23 in-depth personal interviews with researchers, stakeholders, public administrators, and members of social movements who were selected purposefully given their central importance in the case (Patton 2015). In-depth interviews were useful to shed light on "what is at stake?" and on the personal positioning of actors within the field and the heterogeneity of their particular problem setting, as well as their proposed solution to the disease and their narratives about agriculture and their work, roles, and aspirations.

We also had several "key informants": members of a select group of experts who are often most knowledgeable on the issue (Lavrakas 2008). For this purpose, we contacted a researcher working on vector-borne pathogens, a science journalist, and a historian of agriculture to whom we periodically submitted questions and interviews.

\section{RESULTS}

Politics of the bacterium. Among the unintended consequences of the commerce of plants is the movement of plant pathogens. The politics of bacteria appears to be a blend of microbiological protectionism and laissez faire regarding the commerce of cultivars. The central role of the movement of plants or infective vectors transported in plant consignments has been indicated by EFSA in their first report regarding $X$. fastidiosa in Italy (EFSA 2013). Indeed, the so-called CoDiRO strain or Salento-1 strain of $X$. fastidiosa subsp. pauca ST53 most likely arrived in Apulia with ornamental coffee plants from Costa Rica (Giampetruzzi et al. 2017; Marcelletti and Scortichini 2016). The bacterium $X$. fastidiosa was already well regulated by the EU as a quarantine organism under Directives 2000/29/EC and 2002/89/EC. The aim of the Directives is to implement protective measures against the introduction to the European Community of organisms harmful to plant and plant products and to proceed with systematic eradication measures in the event of detection within the EU borders. Although recent studies have indicated the likelihood of a prior presence of the bacterium within EU borders (Soubeyrand et al. 2018), and a "false alarm" during the 1990s regarding potentially infected vines transported between Italy and France (interview), the first detection of X. fastidiosa in Europe was officially declared between October and November 2013 (Bassi et al. 2016). The first regional policy that tackled the problem of OQDS (at the time still called CoDiRO) was the regional council decision number 2023 del 29 October 2013. The regional policy was a direct application of the European Council Directive 2002/89/EC (Luvisi et al. 2017).

Only a few days earlier, a disease note had been published in the Journal of Plant Pathology. This was the scientific report that officially triggered the political process. The page layout of the disease note in the journal caught our interest: two parallel columns, two different outcomes. On the left column the authors reported that in olive plants affected by a "severe decline of unknown etiologies" have been found numerous galleries typical of leopard moth infestation, as well as a number of fungi belonging to Phaeoacremonium spp. (Nigro et al. 2013). In the right column, which reports the first identification of the DNA sequence of $X$. fastidiosa (Saponari et al. 2013), the bacterium is promptly elevated to its "political status". In fact, while insects and fungi generate only research, $X$. fastidiosa, a quarantine organism, also produces policies.

The initial apprehension concerning the political outcomes of the detection of $X$. fastidios $a$ became apparent in an interview with one of the authors of the journal article: "We were hoping it was a laboratory artifact" (interview). From that precise moment, that piece of data starts to shape scientific practices and to prescribe policies and behaviors (Latour 1987; Latour and Wolgar 1986; Lynch 1985). Rather than a pure fact, the polymerase chain reaction positives resulted in new social and political dynamics.

From the end of 2013 to the present day, numerous regional, national, and European policies have been implemented. One of the policies that sparked the most criticism among social movements is the mandatory uprooting of every olive tree in a $100-\mathrm{m}$ radius around the plant where the bacterium has been detected. This 
precautionary phytosanitary measure is based on the long incubation period of $X$. fastidiosa. Plants containing the bacterium can, therefore, be asymptomatic and not showing visible symptoms. Indeed, this element adds some level of complexity to the social perception of the disease. Interestingly, the opposition to this policy is present not only among Apulian social movements but also in some Valencian agricultural association such as ASAJA Alicante and Plataforma de Afectados de la Xylella fastidiosa facing the problem of $X$. fastidiosa subsp. multiplex on almond, whose motto is "No al arranque de árboles sanos" ("Stop uprooting healthy trees").

In a conference rich with repercussions held at the university of Lecce in June 2018, to an audience composed of scientists, stakeholders, administrators, representatives of social movements, and activists, the governor of Apulia began his speech by saying "You must excuse me, but this was my first time". The governor referred in this way to his first time as decision maker and administrator immersed in a process of construction and consolidation of a scientific fact. When the governor of Apulia said that the "postnormal" scientific uncertainty (Funtowicz and Ravetz 1992; Ravetz 2006) made his decisions difficult, he was referring to the amount of time passed between the first detection of $X$. fastidiosa (Saponari et al. 2013) and the completion of Koch's postulates that finally proved the bacterium's pathogenicity on Apulian olive trees (Saponari et al. 2017). Four years are the blink of an eye for a research community but an eternity for a policymaker. The governor lamented that the speed of political decision making is faster than the speed of scientific consensus formation (Collins and Evans 2009).

What drove the contingent phytosanitary policies applied in Apulia? In other words, what was the political problem setting? First of all, we may have to draw a distinction between EU policies and local policies. Whereas EU policies aim at the bacterium (the known), local policies aim at OQDS (the unknown). Indeed, the EU political decision-making process focused its attention on the quarantine pathogen within its territory, seeking precautionary measures to respond to the risks posed by $X$. fastidios a not only to Apulian olive orchards but also to all of the potential host species in Europe and the Mediterranean basin. In contrast, local decisionmakers and local administrators had to deal with the problem of OQDS (and CoDiRO) not only as a political phytosanitary problem but also as an epistemic problem (i.e., a problem of scientific consensus regarding the pathogenicity of the bacterium).

Politics of research. By "politics of research", we define a set of strategies used by an institution with the aim of designing and directing the development of science, especially through the allocations of structural resources (Cerroni 2006; Cerroni and Simonella 2014). Politics of research regarding the disease have been at the center of the criticism voiced by social movements. Social movements believe that the research on the disease has been politically monopolized by the research institutes working on $X$. fastidiosa as the sole cause of OQDS at the expense of other scientific approaches coming from institutes and researchers interested in researching the causes of olive decline. From the very beginning of the spread of the disease in Apulia, different institutional actors have participated in the formation of scientific committees, task forces, and research programs on this issue.

In this section, we will focus on a comparison between the research projects organized by the EU and those organized by the regional administration of Apulia to see how problem setting and problem solving are differently addressed. The problem of legitimacy and extension (Collins and Evans 2002, 2009), discussed in the Theoretical Background section above, can be useful to investigate the dynamics that set up the politics of research on $X$. fastidiosa and OQDS in Europe and Apulia.

H2020 projects, financed by the EC POnTE and XF-ACTORS programs and coordinated by the CNR IPSP of Bari, brought together an extraordinary number of European (as well as inter- national) research institutes that are tackling the problem of $X$. fastidiosa based on its biology, genetics, vectors, disease control, diagnostics, and disease dynamics (the bacterium-vector-host triangle). In contrast, we saw a different scenario with research projects financed by regional funds. That is the case with Parco Ricerca CoDiRO, a regional project promoting a call for experimental projects involving different actors, even members of social movements that found the opportunity to put into practice their ideal $360^{\circ}$ research on CoDiRO, including those lines of research omitted (or perceived to be omitted) such as the study of soil microbiota, soil pollution, and agronomic practices aimed at various fungi considered by many of them to be a contributory cause of CoDiRO. In this regard, two research projects are worthy of mention. The first is SILECC, which aims to reduce the symptoms of decline using agroecological techniques and approaches such as green manuring, biofumigation, and copper-based fertilizers in order to mitigate bacteria, fungi, nematodes, and insects. The other is a project called BICC that aims to revitalize infected plants through the application of a select group of endo- or ectomycorrhizae, fungi, and bacteria that are inoculated to the roots of the plant. Interestingly, neither project mentions the bacterium $X$. fastidiosa.

The EU funding mechanisms support the recognized expertise in the scientific fields of $X$. fastidiosa, addressing the problem of legitimacy by drawing a distinct line between certified experts and noncertified experts. Regional administrators, on the other hand, had to extend the boundaries of the problem setting and problem solving to the range of experience-based expertise in the area. Furthermore, we can argue that the main distinction between EU and regional politics of research resides in the exclusive role of $X$. fastidiosa as the only factor determining the disease; in other words, the distinction between OQDS (as a complex of symptoms caused only by the bacterium) and CoDiRO (as a complex of causes).

Iudex peritus peritorum: Expert of the experts. The "trias politica" (legislative, executive, and judiciary) is the base of our democratic society. Indeed, in a democratic society, even knowledge producers and workers such as academics and researchers must be held accountable for their actions. The relationship between science and law is dynamic (Cerroni and Simonella 2014). For example, law can deal with ethical issues within science and scientific activities; on the other hand, science may help the law when a state (the legal power) needs scientific assessments and scientific data to make a decision.

The relationship between science, ethics, and law is intrinsically linked to the question of governance. Nevertheless, the right to democratic participation does not automatically improve governance and democratic processes. It is not always certain that broadening public involvement improves the decision-making process (Cerroni and Simonella 2014). On the contrary, in some cases, the accountability that forms the basis for governance can exacerbate tensions and controversies, bringing the parties to an endless deconstruction of each other's positions (Jasanoff 2003).

To the broad public, the "case" of $X$. fastidosa in Italy is known to be one of those moments in which scientists have been put on trial for their work (Abbott 2015). On 20 May 2014, social movements and environmental and civic organizations presented a complaint to a local prosecutor that triggered an investigation aimed at clarifying scientists' responsibility in the OQDS epidemic in Apulia. A year later, on 18 December 2015, the same local prosecutor blocked the eradication plans proposed in the emergency plan and sent a notification of impending investigation to researchers from CNR-IPSP and IAMB and other professional figures who had a role in the phytosanitary emergency management of $X$. fastidiosa in Apulia. The charges were: "spreading of plant disease", "unintentional violation of environmental laws", "forgery of public deeds", "conceptual falsity", "diffusion of hazardous material", and "defacement of natural beauty". 
During a press conference, the prosecutor declared: "The European Union has been misled by a false representation of the Xylella fastidiosa emergency, based on improper data and on the nonexistence of a real causal link between the bacterium and the desiccation of plants". What is particularly interesting for our analysis is that a judicial process performed an incursion into the epistemic field.

The prosecutor presented clear problem setting and problem solving for the plant disease OQDS. As mentioned before, phytosanitary policies in Apulia were not aimed at the particular disease per se but, instead, at impeding the possibility that a bacterium confirmed to be "generally" pathogenic could have spread even more. The prosecutor, instead, based his judgments on the likelihood of pathogenicity of the bacterium. The prosecutor treated a political process (the phytosanitary policies) as an epistemic process (its causal role in OQDS). The judicial assessments reflected the problem setting and problem solving methods of the social movements which were opposed to the scientific consensus concerning $X$. fastidiosa in Apulia. The prosecution based its actions on a precise scientific position, a precise problem setting also shared by a certain number of experts: $X$. fastidiosa was not the main etiological factor causing OQDS; the pathogen may have damaged the weaker plants (i.e., those in polluted and poor soils), whereas the areas with more organic agricultural land were less affected by OQDS; and the onset of OQDS symptoms may be affected by fungi, the microbial depletion of agricultural soils, and poor agronomic practices. Accordingly, the problem-solving methods suggested by the prosecutor were the same suggested in the narratives of social movements: good farming practices aimed at restoring the soil biota. According to this viewpoint, the emergency-based policies and the resulting research policies failed to address these questions creating, as a result, an unexplored nonknowledge and an undone science.

Etymologies and etiologies. CoDiRO is often, and erroneously, referred to as the equivalent of OQDS in its English translation. By looking at some the first papers and articles published immediately after the outbreak of 2013, we will try to briefly reconstruct the evolution of the use of the term over time, trying to deliver something between an etymological and historical account of the disease (Fig. 2).

When the first signs of decline were reported on olive trees in southern Apulia in 2013, investigations led to the identification of a complex of symptoms. Such symptoms consisted of leaf scorching and dieback of twigs and branches on old olive plants of the varieties Ogliarola and Cellina di Nardò (Nigro et al. 2013; Saponari et al. 2013). These first field investigations reported a co-occurrence of a possible complex of causes: (i) Zeuzera pyrina, the leopard moth, an insect that feeds on the wood of various trees and shrubs; (ii) a variety of fungi such as Phaeocremoniun, Phemoniella, Pleurostomophora, and Neofusicoccum spp. (Carlucci et al. 2013a, b, 2015; Nigro et al. 2013) and (iii) the bacterium $X$. fastidiosa (Saponari et al. 2013).

At first, the disease was described as "severe olive decline of unknown etiology" (Nigro et al. 2013). Later, the description was formalized with the term CoDiRO, which is literally translated as

\section{ETYMOLOGIES AND ETIOLOGIES}

Draft Genome Sequence Xylella fastidiosa CoDiRO strain

(Giampetruzzi et al., 2015)
Complete Genome Sequence Olive-Infecting Strain Xylella fastidiosa subsp. pauca De Donno (Giampetruzzi et al., 2017)

Genome sequencing of $X$. fastidiosa pauca ST53

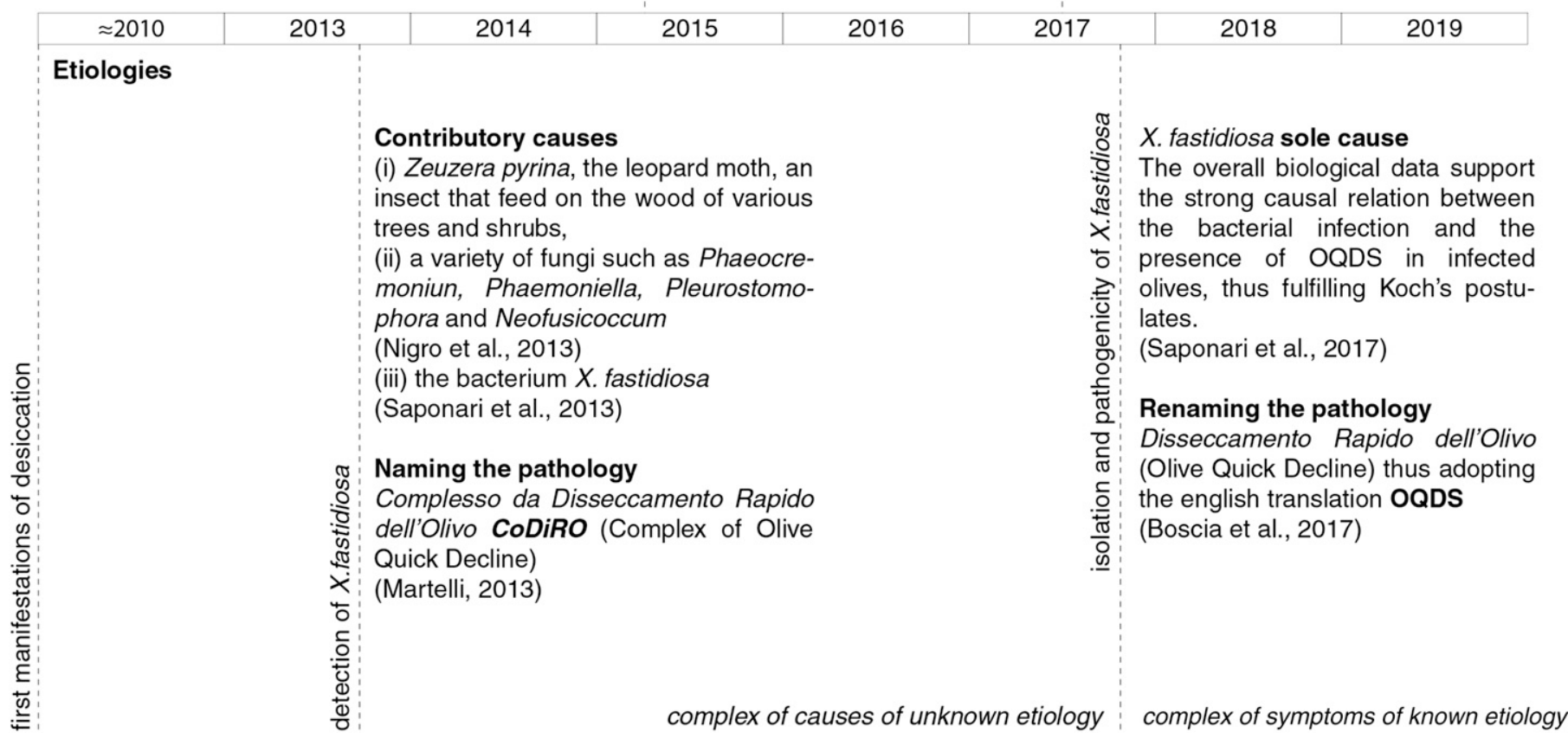

FIGURE 2

Partial timeline of the study of Xylella fastidiosa in Apulia and its relationship to the etymologies and etiologies of olive quick decline syndrome (OQDS; a complex of symptoms) and "complesso del disseccamento rapido dell' olivo" (CoDiRO; a complex of causes). 
"complex of quick olive decline". The term "complex", in this initial definition, refers to the complex of causes, a variety of causes contributing (together) to the disease.

Over time, extended field investigations and the results from the first experimental evidence of transmission demonstrated the etiological role played by X. fastidiosa (Martelli et al. 2016; Saponari et al. 2014). At the same time, the role of fungi and insects became gradually less important (Martelli et al. 2016), until the bacterium was definitively confirmed to be pathogenic in 2017 (Saponari et al. 2017). The confirmation that X. fastidiosa was the decisive factor in causing the disease syndrome led to a need to revise the original name of the disease to the more simplified, English terminology "olive quick decline syndrome", translated into Italian as "disseccamento rapido dell'olivo" (olive quick decline) (Boscia et al. 2017). Although this might seem no more than a terminological clarification, the term changed in its very meaning. From a term indicating a complex of causes, it became a term indicating a complex of symptoms: a variety of symptoms identifiable in one sole cause, the bacterium $X$. fastidiosa.

For a part of the local research community, the term CoDiRO almost resembles a burden to be shaken off. Although CoDiRO had been supplanted by OQDS, it continued to appear regularly in the press, in political statements, in the scientific literature, and, at the end of its journey, in the name used to identify its type strain $X$. fastidiosa subsp. pauca CoDiRO (Boscia et al. 2017).

The point of this immersion into the etymology of the term given to the disease is important to understand its socially perceived etiology. CoDiRO is the term that social movements use, not merely for language preferences but because CoDiRO represent their nonknowledge and their spaces of political and epistemic action. Indeed, social movements in Apulia refuse to accept $X$. fastidiosa as the main etiological factor determining the decline of olive trees in Apulia. Hence, problem setting by social movements diverges from that of the scientific expertise of OQDS, yet it comes from the same origins, a time in which different types of nonknowledge coexisted. Consequently, even their ideal problem solving diverges. In the aftermath of the pathogen eradication plans, we have seen a conflict as well as a separation between the two different explanations about the pathologization (problem setting) and medicalization (problem solving) of OQDS (Fig. 2). In Apulia, social movements have generated an epistemic critique of $X$. fastidiosa as the etiological factor determining OQDS, and a political critique of scientific institutes that first produced that association: a critique of those politics of research that have funded and backed the study of the "reductionistic" OQDS instead of the "holistic" CoDiRO.

By using the term CoDiRO, movements have conducted a lexical reappropriation that generated a socio-epistemic outcome. The term was reinterpreted, reassembled, and replaced as a definition of a complex of causes, their undone science. Social movements have always believed that $X$. fastidiosa was not the problem-that it was not the cause of CoDiRO - and have moved from that base to formulating a wider critique of environmental and social problems that have long been a part of the agricultural system in Apulia and part of their direct experience. CoDiRO could be caused by fungi, soil contamination, poor agronomic practices, and nefarious European policies. CoDiRO is a term that encapsulates not only a wide range of biotic and abiotic factors but also political, anthropological, and sociological factors; it could be interpreted as the term that addressed the initial scientific uncertainty toward the etiological role of $X$. fastidiosa (an uncertainty that has since become certainty), performed by the movements' holistic narrative and their mobilization for $360^{\circ}$ research: "We cure CoDiRO, the bacterium is not our business" (interview).

The $360^{\circ}$ approach. Above, we discussed two important cases in the sociology of scientific controversies. These cases showed how a social science perspective can help understand the relation- ship between recognized experts and members of the public with specialized expertise gained through experience but which is not officially recognized (Collins and Evans 2002, 2009). Brian Wynne's case described the relationship between scientists and Cumbrian sheep farmers after the radioactive fallout from the Chernobyl disaster. Although local sheep farmers' experiencebased knowledge and expertise was determinant, scientists and government officials were reluctant to take any advice from them (Wynne 1989, 1992). According to Collins and Evans (2002), what recognized experts (scientists) and experience-based experts (sheep farmers) needed at the time, was an IE, the capacity to communicate with each other and value each other's knowledge to produce an optimum outcome. On the other hand, in Steven Epstein's case study, IE was successfully used by AIDS treatment activists in the United States, who found that they had to learn the language of specialists and recognized experts in order to make their stances heard in the specialist community that worked on the AIDS clinical trial process (Collins and Evans 2002; Epstein 1995). In our case, we defined social movements as a group of people who, through organized political action, intervene in the epistemic field (Frickel et al. 2010; Hess 2016). These social movements reclaim a different approach to the study of OQDS, the undone science of CoDiRO, that in their opinion runs the risk of being left unexplored. Their $360^{\circ}$ approach aims at widening both the epistemic horizons of nonknowledge, in terms of scientific approaches, and the research policy horizons, in terms of the experts required for the task.

In an interview with a plant pathologist, we asked his opinion about a particular member of the social movements organized around the Xylella emergency, a farmer and activist who we considered to be one of the most experienced and politically active. "What do you think of $(\mathrm{X})$ ?" "Well...I must say...I really respect him, $(\mathrm{X})$ is one of the few people in there that really understands... that really knows about agriculture. The others are mostly ignorant about agriculture...But (X).... Well, I'll give him the honors of war". With these words, the plant pathologist acknowledged a politically unrecognized expertise, and found an epistemic common ground with a farmer. He recognized his opponent's experiencebased expertise based on a shared knowledge of agriculture. However, by saying, "The others are mostly ignorant about agriculture", the researcher simultaneously defined a crucial boundary in his problem of extension. The scientist credited only the experience-based expertise of one particular member of the social movements, one who shared neither his personal nor his professional problem setting and problem solving approach to OQDS but who the scientist nevertheless recognized as sharing the same battleground in the war of ideas. At the same time the scientist precluded any possible interaction with the other activists (nonfarmers and nonexperience-based experts).

Before the detection of $X$. fastidiosa in 2013, scientific expertise and experience-based expertise lived together, coexisting in the same epistemic field of agriculture. The scientists practiced their expertise in the lab; the farmers practiced their experience on the land. The farmer always knew how to deal with brusca (Stictis panizzei), carie (wood decay fungi), fumaggine (sooty mold), rogna (Pseudomonas savastanoi pv. savastanoi), verticillosi (Verticillium dahliae), and other common olive diseases, and the scientist did as well. However, starting in 2013, a bacterium visible only through laboratory-based expertise ended up making the farmer's experience obsolete. $X$. fastidiosa determined the end of the farmer's agency.

The arrival of $X$. fastidiosa in Apulian agriculture marked a political and epistemic rupture: the end of a socially recognized agency, medicated through the imposition of mandatory policies; and the end of the experience-based expertise, torn from the fields of traditional agriculture and reconfined to the experts' laboratories. The answer to this reductionist process was a call to a social holism, a multidisciplinary expertise. The $360^{\circ}$ approach describes not only 
the epistemic and political broadening of research into the scientific nonknowledge of CoDiRO but also the inclusion of other actors with different expertise, not only in agriculture. Social movements are composed of farmers, agronomists, researchers, journalists, law professors, experts in science communication, media figures, environmentalists, and political activists. A swarm of diverse expertise, ambitions, and attitudes, through organized political action, delivers a parallel (or counter) knowledge, the undone science of CoDiRO. What is at stake for Apulian social movements are not only the olive trees of Salento or Valle d'Itria but also their roles as epistemic and political actors. The invisible bacterium not only threatens agriculture but also threatens social and anthropological balances. Although OQDS is "only" a phytopathology, CoDiRO is a socio-phytopathology.

Framing the problem setting and problem solving of OQDS and CoDiRO. A summary of the problem setting and problem solving approaches attributed to different actors is provided in Table 1. With regard to the political actors, we argued that EU problem setting and problem solving is centered on the regulations concerning quarantine pathogens. $X$. fastidiosa is a pathogen that poses a threat not only to the olive trees of Apulia but also to more than 300 potential host species. If the EU problem setting is limited to the presence in its territory of a quarantine organism, it follows that its problem solving is focused on the implementation of containment and eradication strategies. In contrast, local political actors in Apulia must address a dual problem: the problem of OQDS, represented by the presence of the bacterium in its territory, and the problem of CoDiRO as a social and scientific controversy, hence trying to include in the epistemic process the widest number of experts and experience-based experts form social movements.

For scientific researchers, the problem represented by the disease is addressed differently. Drawing on Karin Knorr-Cetina's notion of "epistemic cultures" (Knorr-Cetina 1999), Böshen et al. (2006) argued that scientific disciplinary fields (different expertise) are characterized not only by different approaches to knowledge making (Knorr-Cetina 1999) but also by their different approach to ignorance. Indeed, divergent orientations to control complexity lead actors (the particular expertise) to treat what is not known in different ways (Kleinman and Suryanarayanan 2013). Depending on their particular field of expertise, different experts define different types of nonknowledge. Entomologists may locate nonknowledge within the mechanisms of transmission by vectors; plant pathologists may think about searching for sources of tolerance, resistance, or even immunity to the pathogen; and plant physiologists may address the problem via the lack of organic matter in Apulian soils.

The nonknowledge of OQDS is centered around the infection as an exceptional event. In this sense, $X$. fastidiosa represents the only variable to take into consideration; hence, the most logical way to frame the problem is to narrow down the research to the study of the interaction between the bacterium, its hosts, and its vectors. The agricultural stakeholders have demonstrated a clear affinity to this nonknowledge. For example, when, last year, a study (a regionaland EU-funded project called EPIZIXI) finally proved that fungi have no determining role in OQDS, an agricultural entrepreneur wrote on his personal Facebook page: "As if another proof was even needed, fungi have nothing to do with OQDS...CoDiRO does not exist! Deal with it!" Stakeholders have often criticized the political handling of the emergency but, at the same time, we noticed that they usually trust science policies and support scientific efforts aimed at finding rapid solutions to a sector on the brink of collapse.

On the other hand, the nonknowledge of CoDiRO focuses on contributory factors that may have had some impact on the emergence of the disease. This approach is centered on plant-soil interactions and environmental factors that may facilitate the onset of decline: variables such as water deficit, lack of organic matter in the soils, and other physiological stresses (Xiloiannis et al. 2015). Indeed, this approach represents, in some ways, a point of convergence between part of the scientific community and the social movements. Social movements argue that the main reason for the disease is the lack of organic matter in soils. "There can't be no healthy plant on an ill soil" (interview). Some of them argue that the bacterium found a favorable environment in the microbiologically poor soils of Apulia. The lack of organic matter in Apulian soils is believed to be caused by years of abuse of agrochemical products stemming from years of poor agronomic practices which are the results of years of questionable agriculture policies. Sometimes, issues presented by social movements have been backed by

TABLE 1

Framing actors' problem setting and problem solving in the case of olive quick decline in Apulia ${ }^{a}$

\begin{tabular}{|c|c|c|}
\hline Actors & Problem setting & Problem solving \\
\hline European Union & Xylella fastidiosa & $\begin{array}{l}\text { Eradication and containment } \\
\text { measures, funding research on } \\
\text { Xylella }\end{array}$ \\
\hline Puglia Region & X. fastidiosa, OQDS, CoDiRO & $\begin{array}{l}\text { Eradication and containment } \\
\text { measures, funding research on } \\
\text { OQDS and CoDiRO }\end{array}$ \\
\hline Infection centered & OQDS bacterium-host-vector & $\begin{array}{l}\text { Eradication and containment } \\
\text { strategies; resistant, tolerant, or } \\
\text { immune cultivars }\end{array}$ \\
\hline Environmental factors centered & CoDiRO water-soil-plant & $\begin{array}{l}\text { Sustainable agronomic practices, } \\
\text { biofertilizers }\end{array}$ \\
\hline Social movements & CoDiRO & $360^{\circ}$ approach \\
\hline
\end{tabular}


members of the scientific community; for example, the implementation of the highly criticized "Martina Decree" entailing the massive use of pesticides to reduce vector population (including neonicotinoids), was labeled "indefensible" by a local entomologist.

Some members of the scientific community were also invited to participate in events organized by social movements such as the case of a bacteriologist experimenting with the product Dentamet, a zinc and copper fertilizer combination aimed at reducing the concentration of the bacterium in the plant, hence reducing the visible symptoms of the disease (Scortichini et al. 2018). In contrast, social movements tend to strongly disagree with those researchers and institutes that support a firm implementation of phytosanitary policies, or that propose research on sources of resistance to $X$. fastidiosa as the only attainable solution for saving olive growing in Apulia. Indeed, for social movements, the substitution of autochthonous traditional cultivars such as Ogliarola and Cellina di Nardò with new X. fastidiosa-resistant cultivar such as Fs 17 evokes a dystopic scenario. Convergence between movements and scientists revolves around the necessity to address the problem as systemic or the possibility of a cure for the already affected olive trees.

\section{DISCUSSION}

Time, policy, and experts. In an interview with a researcher supporting the nonknowledge of OQDS, we asked whether there will be some space for the unexplored types of nonknowledge proposed by social movements in the near future. His response was particularly significant: "Firstly, we had to know who our enemy was, we had to delimit its contours... and this can be seen as phase

-

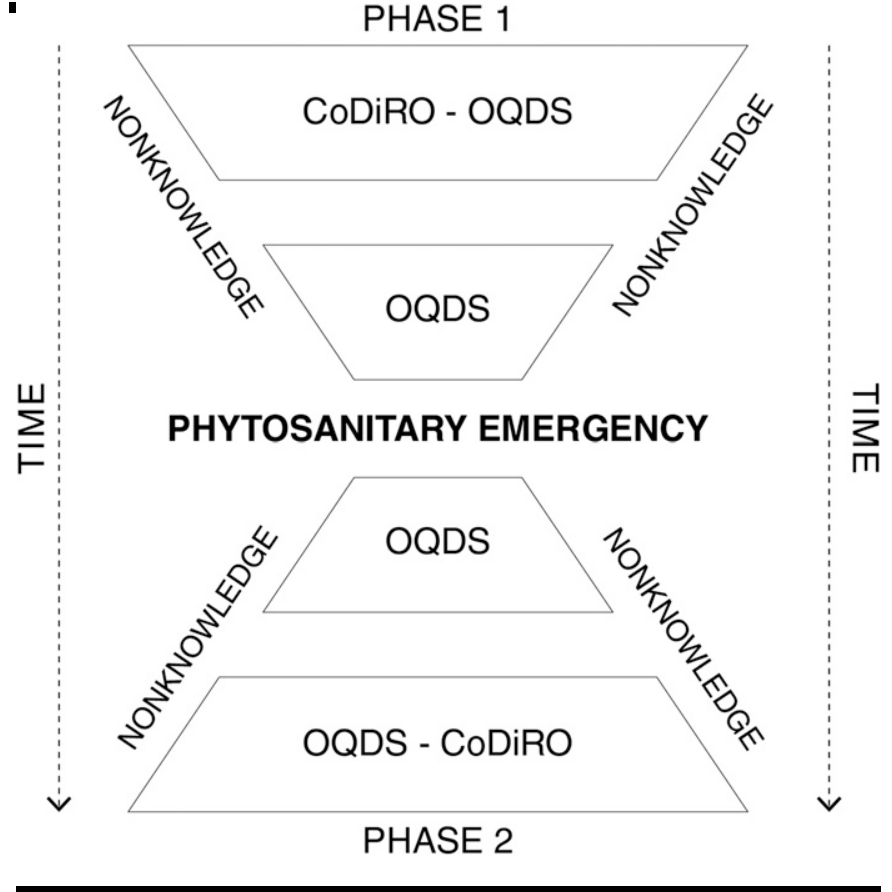

FIGURE 3

Contraction and expansion of nonknowledge (known unknowns considered worth pursuing) over time. Phase 1 shows the nonknowledge of olive quick decline syndrome (OQDS; a complex of symptoms) due to the phytosanitary emergency associated with the detection of Xylella fastidiosa in the European Union. In phase 2, other types of nonknowledge such as the nonknowledge of "complesso del disseccamento rapido dell' olivo" (CoDiRO; a complex of causes) may be included. one...now comes phase two, and we can sit and discuss other factors that may have a role in the pathology". This researcher highlighted the importance of focusing, at least for the "first phase", only on the study of a known objective, the bacterium. This process has emphasized delimiting the nonknowledge of the bacterium $X$. fastidiosa but it has also implicated a designation of a selected group of certified experts who could best address the problem. In the first phase, the nonknowledge of OQDS was epistemically and politically rationalized. It was going through a consolidation process that started in 2013 with the first detection and identification of the bacterium in declining plants (Saponari et al. 2013) and ended in 2017 when $X$. fastidiosa was finally proven to be pathogenic (Saponari et al. 2017). In the first phase of the research on the disease, narrowing down the object of research to the bacterium-host-vector triangle was the necessary starting point not only to guide policies but also to reclaim an epistemic space of action. In this phase one, the nonknowledge of OQDS was also something to defend from the external "attack" arising from the nonknowledge of CoDiRO. The nonknowledge of OQDS was, as a result, entrenched and aware of external perils that might threaten its legitimacy (Fig. 3).

In scientific controversies, where actors across multiple groups struggle over how to understand and respond to a certain issue of concern, asymmetries in the access to resources and power shape what does and does not get ignored (Harding 2000; Kleinman and Suryanarayanan 2013). Some known unknowns are worth pursuing but the already known facts may constitute the place where the pursuit of the unknowns must start. One of these facts is that $X$. fastidiosa is a dangerous quarantine plant pathogen. Picturing nonknowledge worth pursuing must start from the fact that olive trees (cultivars Cellina di Nardò and Ogliarola Salentina), when affected by this bacterium (X. fastidiosa subsp. pauca) which is transported by an insect vector (Philaenus spumarius), are destined to die. In the necessity to frame an urgent and contingent problem and to propose a rapid solution, the policymaker (where power and money are) may opt for certain and assured nonknowledge and decide to maintain spaces of ignorance for strategic purposes (McGoey 2007, 2012). Decisions of public concern have to be made according to a timetable defined within the political sphere, before the scientific dust has settled (Collins and Evans 2002). The limited time and the amount of knowledge at one's disposal (as well as the feasibility of the types of nonknowledge proposed by a group of experts) may guide the critical decision of a policymaker that will select contingent types of nonknowledges and choose among different epistemic culture of nonknowledge, hence defining specific problem setting and problem solving. Through the allocation of funding instruments, policy making outlines the horizons of nonknowledge, automatically defining what knowledge would be placed outside. Each scientific culture of nonknowledge addresses both problem setting and problem solving in a different way but some of them are more suitable for the here and now and, therefore, may be more valuable for the policy-making process. However, although this process can serve to narrow down a scientific object, for other actors such as social movements, this process meant their exclusion: the end of their roles as epistemic and political actors in the research for remedies to OQDS or, better, to CoDiRO. If, indeed, the study of $X$. fastidiosa (its biology, vectors, disease dynamics, and diagnostics) as the sole cause determining the disease is the right path to take, for Apulian social movements, in contrast, $X$. fastidiosa is an emblem of the impossibility to pursue the study of CoDiRO as a complex of causes. The newly narroweddown research on OQDS became, for them, a negative knowledge, considered dangerous and a cause to oppose politically and epistemically. An unknown microscopic bacterium, only detectable through molecular and serological tests through microchips, airborne imaging spectroscopy, and thermography, before the appearance of visible symptoms of decline, escaped their senses and 
perceptions. The experienced eye of a farmer lost its battle to the technology of an expert and Olea europaea, the tree of farmers, soon became the tree of laboratories. However, the boundaries of nonknowledge are not fixed. If the phytosanitary emergency has led to its political and epistemic contraction, overcoming the emergency could allow the boundaries of nonknowledge to expand and to include those types of nonknowledge previously excluded from the political and the epistemic processes. The "phase two" that the aforementioned researcher pictured could represent, if not the inclusion of experience-based experts from movements in the processes of problem setting and solving, at least an epistemic merging of the undone science that movements want to pursue. In this sense, it seems that the nonknowledge of OQDS, at first entrenched, contracted, and limited to a few imperatives (bacteriumhost-vector), would, over time, incorporate some elements taken from the nonknowledge of CoDiRO. A restricted nonknowledge appears to be functional to the state of phytosanitary emergency that, once surpassed and resolved, might expand and include the same types of nonknowledge previously excluded.

\section{CONCLUSIONS}

"Let's open the research at 360 degrees! Let's make Salento an open air phytopathological laboratory" (An activist)

This contribution aimed at providing an account of sociological research on how the detection of X. fastidiosa in Apulia sparked a schism of knowledge orientations regarding the processes of OQDS problem setting and problem solving. We tried to show how questions within the sociology of knowledge, sociology of scientific knowledge, and sociology of ignorance can be useful to analyze this particular case. We do not claim to have fully understood all the stakes involved, and we do not speak for social movements or pretend to "explain" to scientists how science works. Using the theoretical framework of ignorance studies, we tried to reconstruct the dynamics between two different ways of constructing the disease and highlighted how the known unknowns considered worth pursuing are, indeed, relative but, in the end, also have a different weight in the face of the policy-making process during a phytosanitary emergency.

We tried to consider the problem-setting and problem-solving approaches of each actor, although we decided to give more importance to the relationship between social movements and scientists. We do not think that Apulian social movements contest "science" but, rather, the type of scientific nonknowledge that does not align with their problem setting and their problem solving. The majority of social movement members that we met are carriers of praiseworthy political ideas regarding the importance of democratic processes in knowledge societies. The dangers of an epistemic elitism are no less real than the dangers of an epistemic populism. It is easy to get tempted by the idea that if these movements did not exist in the first place, we could have saved millions of olive trees, and that social movements contesting the scientific evidence over the pathogenicity of $X$. fastidiosa are only a group of conspiracy theorists; however, as sociologists, we must take into account complexity and avoid simple explanations.

As we tried to explain in this article, their $360^{\circ}$ approach represents, at its core, the need to address the systemic causes of OQDS, a destructive social and natural event: an epistemic and political broadening of the study of natural, social, economic, and political factors that led to this circumstance. Among these systemic causes we can also find issues already addressed within research communities such as the impact of a globalized commerce in the spread of infectious disease (Tatem et al. 2006) and the effects of global change on the distribution of $X$. fastidiosa in Europe (Godefroid et al. 2018). However, the call for a "disciplinary holism" is not the only reason behind the actions of social movements. In trying to concentrate on the relational aspects pertaining to the sociology of knowledge, we feel that we have not addressed sufficiently other issues concerning the anthropological meaning of living and working in these regions of southern Italy.

In the struggle to save, at all costs, the susceptible and already affected autochthonous cultivars, we can find the will to continue to preserve high-quality and competitive olive oil production; behind the opposition to the use of insecticides against vectors, there are serious health concerns in addition to those already existing in this region; the central focus on the soil starts from the awareness of the high levels of arsenic, beryllium, and vanadium found in the soils of southern Apulia. In some ways, the opposition to official policies and "hegemonic" knowledge represents the tipping point of a widespread social sickness. The problem setting and problem solving of this disease should be addressed at $360^{\circ}$, thereby considering OQDS not merely a phytopathology but, rather, a sociophytopathology.

\section{ACKNOWLEDGMENTS}

We thank the Department of Sociology and Social Research of the University of Milano Bicocca; C. Acosta Sarmiento for her incredible contribution; J. Chialà, M. Bandiera, E. Milazzo. D. Cornara, and T. Simpson (http://xylellacodiro.blogspot.com/) for their help in revising the manuscript; and the researchers and activists who worked with us and those who (hopefully) will in the future.

\section{LITERATURE CITED}

Abbott, A. 2015. Italian Scientists Vilified in Wake of Olive-Tree Deaths. Online publication. Nature News, Nature Publishing Group.

Adler, P. A., and Adler, P. 1994 Observational techniques. Pages 377-392 in: Handbook of Qualitative Research. N. K. Denzin and Y. S. Lincoln, eds. Sage Publications, Thousand Oaks, CA.

Almeida, R., and Nunney, L. 2015. How do plant diseases caused by Xylella fastidiosa emerge? Plant Dis. 99:1457-1467.

Barnes, B. 1974. Scientific Knowledge and Sociological Theory. Routledge \& Keegan Paul, London.

Barnes, B. 1977. Interests and the Growth of Knowledge. Routledge \& Keegan Paul, Boston, London.

Bassi, R., Morelli, G., and Salamini, F. 2016. Accademia dei Lincei, report on Xylella. Online publication. http://www.lincei.it/files/documenti/Rapporto_xylella_20160622.pdf

Bateson, G. 1935. Culture contact and schismogenesis. Man (Lond.) 35: 178-183.

Bloor, D. 1991. Knowledge and Social Imagery, 2nd ed. University of Chicago Press, Chicago.

Boscia, D., Altamura, G., Saponari, M., Tavano, D., Zicca, S., Pollastro, P., Silletti, M. R., Savino, V., Martelli, G. P., Delle Donne, A., Mazzotta, S., Signore, P. P., Troisi, M., Drazza, P., Conte, P., D’Ostuni, V., Merico, S., Perrone, G., Specchia, F., Stanca, A., and Tanieli, M. 2017. Incidenza di Xylella in oliveti con disseccamento rapido. Inf. Agrar. 27/2017:47-50.

Böshen, S., Kastenhofer, K., Marschall, L., Rust, I., Soentgen, J., and Wehling, P. 2006. Scientific cultures of non-knowledge in the controversy over genetically modified organisms (GMO): The cases of molecular biology and ecology. Gaia (Heidelb.) 15:294-301.

Böshen, S., Kastenhofer, K., Rust, I., Soentgen, J., and Wehling, P. 2010. Scientific nonknowledge and its political dynamics: The cases of agribiotechnology and mobile phoning. Sci. Technol. Human Values 35: 783-811.

Carlucci, A., Lops, F., Cibelli, F., and Raimondo, M. L. 2015. Phaeoacremonium species associated with olive wilt and decline in southern Italy. Eur. J. Plant Pathol. 141:717-729.

Carlucci, A., Lops, F., Marchi, G., Mugnai, L., and Surico, G. 2013a. Has Xylella fastidiosa "chosen" olive trees to establish in the Mediterranean basin? Phytopathol. Mediterr. 52:541-544.

Carlucci, A., Raimondo, M., Cibelli, F. J. L., Philips, A., and Lops, F. 2013b. Pleurostomophora richardsiae, Neofusicoccum parvum and Phaeoacremonium aleophilum associated with a decline of olives in southern Italy. Phytopathol. Mediterr. 52:517-527.

Cerroni, A. 2006. Scienza e società della conoscenza. Utet, Torino, Italy.

Cerroni, A., and Simonella, Z. 2014. Sociologia della scienza. Capire la scienza per capire la società contemporanea. Carocci, Rome. 
Chatterjee, S., Almeida, R., and Lindow, S. 2008. Living in two worlds: The plant and insect lifestyles of Xylella fastidiosa. Annu. Rev. Phytopathol. 46: 243-271.

Chiriacò, M. S., Luvisi, A., Primiceri, E., Sabella, E., De Bellis, L., and Maruccio, G. 2018. Development of a lab-on-a-chip method for rapid assay of Xylella fastidiosa subsp. pauca strain CoDiRO. Sci. Rep. 8: Article 7376.

Ciervo, M. 2016. The olive quick decline syndrome (OQDS) diffusion in Apulia Region: An apparent contradiction according to the agricultural model. Online publication. Belgeo 4. https://journals.openedition.org/belgeo/20290

Colella, C. 2016. Distrusting science on communication platforms: Socioanthropological aspects of the science-society dialectic within a phytosanitary emergency. Pages 12-16 in: Proc. 2nd Int. Workshop Social Media World Sensors, 10th Int. Conf. Language Resources and Evaluation. L. Di Caro and M. Cataldi, eds.

Collins, H. 2004. Interactional expertise as a third kind of knowledge. Phenomenol. Cogn. Sci. 3:125-143.

Collins, H., Evans, R., and Gorman, M. 2007. Trading zones and interactional expertise. Stud. Hist. Philos. Sci. 38:657-666.

Collins, H. M., and Evans, R. 2002. The third wave of science studies: Studies of expertise and experience. Soc. Stud. Sci. 32:235-296.

Collins, H. M., and Evans, R. 2009. Rethinking Expertise. University of Chicago Press, Chicago, IL.

Collins, H. M., and Evans, R. 2015. Expertise revisited I: Interactional expertise. Stud. Hist. Philos. Sci. 54:113-123.

Collins, R., and Restivo, S. 1983. Development, diversity, and conflict in the sociology of science. Sociol. Q. 24:185-200.

Cornara, D., Cavalieri, V., Dongiovanni, C., Altamura, G., Palmisano, F., Bosco, D., Porcelli, F., Almeida, R. P. P., and Saponari, M. 2016. Transmission of Xylella fastidiosa by naturally infected Philaenus spumarius (Hemiptera, Aphrophoridae) to different host plants. J. Appl. Entomol. 141: 80-87.

Cornara, D., Saponari, M., Zeilinger, A. R., de Stradis, A., Boscia, D., Loconsole, G., Bosco, D., Martelli, G. P., Almeida, R.P. P., and Porcelli, F. 2017. Spittlebugs as vectors of Xylella fastidiosa in olive orchards in Italy. J. Pest Sci. 90:521-530.

Dongiovanni, C., Cavalieri, V., Altamura, G., Di Carolo, M., Fumarola, G., Corrado, I., Saponari, M., de Lillo, E., and Porcelli, F. 2016. Risultati preliminari di prove comparative di efficacia per il controllo di Philaenus spumarius, vettore di Xylella fastidiosa. ATTI Giornate Fitopatol. 1: 393-402.

EFSA. 2013. Statement of EFSA on host plants, entry and spread pathways and risk reduction options for Xylella fastidiosa Wells et al. EFSA J. 11: 3468.

Epstein, S. 1995. The construction of lay expertise: AIDS activism and the forging of credibility in the reform of clinical trials. Sci. Technol. Human Values 20:408-437.

Epstein, S. 1996. Impure Science: AIDS, Activism, and the Politics of Knowledge. University of California Press, Berkeley, Los Angeles, London.

Frascarelli, A. 2017. L'evoluzione della Pac e le imprese agricole: Sessant'anni di adattamento. Online publication. Agriregioneuropa 13. https:// agriregionieuropa.univpm.it/it/content/article/31/50/levoluzione-della-pace-le-imprese-agricole-sessantanni-di-adattamento

Frickel, S., Gibbon, S., Howard, J., Kempner, J., Ottinger, G., and Hess, D. J. 2010. Undone science: Charting social movement and civil society challenges to research agenda setting. Sci. Technol. Human Values 35:444-473.

Frickel, S., and Gross, N. 2005. A general theory of scientific/intellectual movements. Am. Sociol. Rev. 70:204-232.

Frickel, S., and Moore, K. 2006. The New Political Sociology of Science: Institutions, Networks, and Power. University of Wisconsin Press.

Frickel, S., and Vincent, M. B. 2007. Hurricane Katrina, contamination, and the unintended organization of ignorance. Technol. Soc. 29:181-188.

Frisullo, S., Carmele, I., Agosteo, G. M., Boscia, D., and Martelli, G. P. 2014. Brief historical account of olive leaf scorch ("brusca") in the Salento peninsula of Italy and state-of-the-art of the olive quick decline syndrome. J. Plant Pathol. 96:441-449.

Funtowicz, S. O., and Ravetz, J. R. 1992. Three types of risk assessment and the emergence of post-normal science. Pages 251-273 in: Social Theory of Risk. S. Krimsky and D. Golding, eds. Greenwood, Westport, CT.

Giampetruzzi, A., Saponari, M., Almeida, R. P. P., Essakhi, S., Boscia, D., Loconsole, G., and Saldarelli, P. 2017. Complete genome sequence of the olive-infecting strain Xylella fastidiosa subsp. pauca De Donno. Genome Announc. 5:e00569-17.

Giampetruzzi, A., Chiumenti, M., Saponari, M., Donvito, G., Italiano, A., Loconsole, G., Boscia, D., Cariddi, C., Martelli, G. P., and Saldarelli, P. 2015. Draft genome Sequence of Xylella fastidiosa CoDiRO Strain. Genome Announc. 3:e01538-14.
Godefroid, M., Cruaud, A., Streito, J. C., Rasplus, J. Y., and Rossi, J. P. 2018. Climate change and the potential distribution of Xylella fastidiosa in Europe. Online publication. bioRxiv 289876.

Godini, A. 2017. Breve Storia Dell'olivicoltura. Online publication. OlioOfficina Magazine. www.olioofficina.it/saperi/economia/breve-storia-dell-olivicoltura.htm

Gross, M. 2007. The unknown in process: Dynamic connections of ignorance, nonknowledge and related concepts. Curr. Sociol. 55:742-759.

Gross, M. 2010. Ignorance and Surprise, Science, Society, and Ecological Design. MIT Press

Harding, S. 2000. Should philosophies of science encode democratic ideals? Pages 121-138 in: Science, Technology, and Democracy. D. L. Kleinman, ed. State University of New York Press, Albany.

Hess, D. 2007. Ethnography and the development of science and technology studies. Pages 1-15 in: Handbook of Ethnography. P. Atkinson, A. Coffey, S. Delamont, J. Lofland, and L. Lofland, eds.

Hess, D. J. 2009. The potentials and limitations of civil society research: Getting undone science done. Sociol. Inq. 79:306-327.

Hess, D. J. 2016. Undone Science: Social Movements, Mobilized Publics, and Industrial Transitions. MIT Press, Cambridge, MA.

Irwin, A., and Wynne, B., eds. 1996. Misunderstanding Science? The Public Reconstruction of Science and Technology. Cambridge University Press, Cambridge, New York, Melbourne.

Jasanoff, S. 2003. Technologies of Humility: Citizen Participation in Governing Science. Minerva 41:223.

Kleinman, D. L., and Suryanarayanan, S. 2013. Dying bees and the social production of ignorance. Sci. Technol. Human Values 38:492-517.

Knorr-Cetina, K. 1999. Epistemic Cultures: How the Sciences Make Knowledge. Harvard University Press, Cambridge, MA.

Kozinets, R. V., and Handelman, J. 1998. Ensouling consumption: A netnographic exploration of the meaning of boycotting behavior. Pages 475-480 in: Advances in Consumer Research, Vol. 25. J. W. Alba and J. W. Hutchinson, eds. Association for Consumer Research, Provo, UT.

Kuhn, T. S. 1962. The Structure of Scientific Revolution. University of Chicago Press, Chicago, IL.

Kuhn, T. S. 1970. The Structure of Scientific Revolution, 2nd ed. enlarged. University of Chicago Press, Chicago, IL.

Latour, B. 1987. Science in Action: How to Follow Scientists and Engineers Through Society. Harvard University Press, Cambridge, MA.

Latour, B., and Wolgar, S. 1986. Laboratory Life: The Construction of Scientific Facts. Princeton University Press, Princeton, NJ.

Lavrakas, P. J. 2008. Key informants. Page 407 in: Sage Encyclopedia of Survey Research Methods. Sage Research Methods, Thousand Oaks, CA.

Loconsole, G., Potere, O., Boscia, D. 2014. Detection of Xylella fastidiosa in olive trees by molecular and serological methods. J. Plant Pathol. 96: 7-14.

Luvisi, A., Nicolì, F., De Bellis, L., and De Bellis, L. 2017. Sustainable management of plant quarantine pests: The case of olive quick decline syndrome. Sustainability 9:659.

Lynch, M. 1985. Art and Artifact in Laboratory Science: A Study of Shop Work and Shop Talk in a Research Laboratory. Routledge \& Kegan Paul, Abington, UK.

Marcelletti, S., and Scortichini, M. 2016. Xylella fastidiosa CoDiRO strain associated with the olive quick decline syndrome in southern Italy belongs to a clonal complex of the subspecies pauca that evolved in Central America. Microbiology 162:2087-2098.

Martelli, G. P., Boscia, D., Porcelli, F., and Saponari, M. 2016. The olive quick decline syndrome in south-east Italy: A threatening phytosanitary emergency. Eur. J. Plant Pathol. 144:235-243.

Mastrolia, F. 1996. Agricoltura, Innovazione e Imprenditorialità in Terra d'Otranto nell'Ottocento. Edizioni Scientifiche Italiane, Napoli, Italy.

Mastrolia, F. 2000. Istituzioni e Conoscenze Agrarie in Terra d'Otranto (18101910). Edizioni Scientifiche Italiane, Napoli, Italy.

Mazzotti, M. 2004. Enlighted mills: Mechanizing olive oil production in Mediterranean Europe. Technol. Cult. 45:277-304.

McGoey, L. 2007. On the will to ignorance in bureaucracy. Econ. Soc. 36: 212-235.

McGoey, L. 2012. Strategic unknowns: Toward a sociology of ignorance. Econ. Soc. 41:1-16.

Nández, G., and Borrego, Á. 2013. Use of social networks for academic purposes a case study. Electron. Libr. 31:781-791.

Nigro, F., Boscia, D., Antelmi, I., and Ippolito, A. 2013. Fungal species associated with a severe decline of olive in Southern Italy. J. Plant Pathol. 95: 668.

Oldroyd, D. R. 1989. The Arch of Knowledge: An Introductory Study of the History of the Philosophy and Methodology of Science. NSWU Press

Patton, M. Q. 2015. Qualitative Research and Evaluation Methods: Integrating Theory and Practice, 4th ed. Sage, Thousand Oaks, CA. 
Primavera, M., D’Oronzo, C., Muntoni, I. M., Radina, F., and Fiorentino, G. 2017. Environment, crops and harvesting strategies during the II millennium BC: Resilience and adaptation in socio-economic systems of Bronze Age communities in Apulia (SE Italy). Quat. Int. 436:83-95.

Purcell, A. H. 2013. Paradigms: Examples from the bacterium Xylella fastidiosa. Annu. Rev. Phytopathol. 51:339-356.

Purcell, A. H., and Hopkins, D. L. 1996. Fastidious xylem-limited bacterial plant pathogens. Annu. Rev. Phytopathol. 34:131-151.

Ravetz, J. R. 2006. Post-normal science and the complexity of transitions towards sustainability. Ecol. Complex. 3:275-284.

Saponari, M., Boscia, D., Altamura, G., Loconsole, G., Zicca, S., D’Attoma, G., Morelli, M., Palmisano, F., Saponari, A., Tavano, D., Savino, V. N., Dongiovanni, C., and Martelli, G. P. 2017. Isolation and pathogenicity of Xylella fastidiosa associated to the olive quick decline syndrome in southern Italy. Sci. Rep. 7: Article 17723.

Saponari, M., Boscia, D., Nigro, F., and Martelli, G. P. 2013. Identification of DNA sequences related to Xylella fastidiosa in oleander, almond and olive trees exhibiting leaf scorch symptoms in Apulia (southern Italy). J. Plant Pathol. 95:668.

Saponari, M., Loconsole, G., Cornara, D., Yokomi, R. K., De Stradis, A., Boscia, D., Bosco, D., Martelli, G. P., Krugner, R., and Porcelli, F. 2014. Infectivity and transmission of Xylella fastidiosa by Philaenus spumarius (Hemiptera: Aphrophoridae) in Apulia, Italy. J. Econ. Entomol. 107: 1316-1319.

Scortichini, M., Chen, J., de Caroli, M., Dalessandro, G., Pucci, N., Modesti, V., L'Aurora, A., Petriccione, M., Zampella, L., Mastrobuoni, F., Mignoni, D., Del Coco, L., Girelli, C. R., Piacente, F., Piacente, F., Cristella, N., Marangi, P., Laddomada, F., Di Cesare, M., Cesari, G., Fanizzi, F. P., and Loreti, S. 2018. A zinc, copper and citric acid biocomplex shows promise for control of Xylella fastidiosa subsp. pauca in olive trees in Apulia region (southern Italy). Phytopathol. Mediterr. 57:48-72.

Selinger, E., Dreyfus, H., and Collins, H. 2007. Interactional expertise and embodiment. Stud. Hist. Philos. Sci. 38:722-740.

Shoham, A. 2004. Flow experiences and image making: An online chat-room ethnography. Psychol. Mark. 21:855-882.

Sotte, F. 2017. Sessant'anni di Europa e Pac: Il nuovo che c'è e il vecchio che è rimasto. Online publication. Agriregioneuropa 13. https://agriregionieuropa.univpm.it/it/content/article/31/50/sessantanni-di-europa-e-pac-ilnuovo-che-ce-e-il-vecchio-che-e-rimasto

Soubeyrand, S., de Jerphanion, P., Martin, O., Saussac, M., Manceau, C., Hendrikx, P., and Lannou, C. 2018. Inferring pathogen dynamics from temporal count data: The emergence of Xylella fastidiosa in France is probably not recent. New Phytol. 219:824-836.

Strona, G., Carstens, C. J., and Beck, P. S. A. 2017. Network analysis reveals why Xylella fastidiosa will persist in Europe. Sci. Rep. 7:Article 71.

Swanson, H. A., Lien, M. E., and Ween, G. B. 2018. Domestication Gone Wild: Politics and Practices of Multispecies Relations. Duke University Press

Tatem, A. J., Rogers, D. J., and Hay, S. I. 2006. Global transport networks and infectious disease spread. Adv. Parasitol. 62:293-343.

Tsing, A. 2015. Feral biologies. Invited lecture, "Engagements: The anniversary of anthropology in Copenhagen." Department of Anthropology, University of Copenhagen.

Wagner, R. 1981. The Invention of Culture. Revised and Expanded Edition. University of Chicago Press, Chicago, IL.

White, S. M., Bullock, J. M., Hooftman, D. A. P., and Chapman, D. S. 2017. Modelling the spread and control of Xylella Fastidiosa in the early stages of invasion in Apulia, Italy. Biol. Invasions 19:1825-1837.

Wynne, B. 1989. Sheepfarming after Chernobyl: A case study in communicating scientific information.Environment: Sci. Policy Sustain. Dev. 31:10-39.

Wynne, B. 1992. Misunderstood misunderstanding: Social identities and public uptake of science. Public Understandings Sci. 1:281-304.

Xiloiannis, C., Lardo, E., Sofo, A., and Palese, A. M. 2015. Contro Xylella su olivo le buone pratiche agronomiche. Inf. Agrar. 19/2015:49-53.

Zarco-Tejada, P. J., Camino, C., Beck, P. S. A., Calderon, R., Hornero, A., Hernández-Clemente, R., Kattenborn, T., Montes-Borrego, M., Morelli, M., Gonzales-Dugo, V., North, P. J. R., Landa, B. B., Boscia, D., Saponari, M., and Navas-Cortes, J. A. 2018. Previsual symptoms of Xylella Fastidiosa infection revealed in spectral plant-trait alterations. Nat. Plants 4:432-439.

\section{AUTHOR-RECOMMENDED INTERNET RESOURCES}

Regulation Number 136/66/EEC: https://eur-lex.europa.eu/legal-content/en/ ALL/?uri=CELEX\%3A31966R0136

Parco Ricerca CoDiRO: http://www.comune.galatone.le.it/documenti/notizie/ Progetti_parco_ricerca_CODIRO.pdf

European Union December 2015 prosecutor statement: https://agronotizie. imagelinenetwork.com/agricoltura-economia-politica/2015/12/21/xylellala-procura-di-lecce-blocca-il-piano-silletti/46949

Levels of arsenic, beryllium, and vanadium in soil: http://www.geneosalento.it/ index.php? $\mathrm{r}=$ site/results 